\title{
An assessment of private television broadcasting operations in Nigeria
}

\author{
Akpor Ewomazino a,1,* \\ ${ }^{a}$ Edo university Iyamho, Km7, Auchi-Abuja Road, Iyamho-Uzairue Edo State, Nigeria. \\ ${ }^{1}$ akpor.ewomazino@edouniversity.edu.ng* \\ * corresponding author
}

ARTICLE INFO

Article history

Received 2020-09-14

Revised 2020-11-22

Accepted 2021-01-08

Keywords

Broadcast

Deregulation

Monopoly

Regulation

Programming

\section{ABSTRACT}

This study examines the challenges of private broadcasting in Nigeria with particular reference to African Independent Television (AIT), Yenagoa, as the case study. The wake of private broadcasting in Nigeria came with decree 38 of 1992 under the General Ibrahim Babangida Administration. This overtime leads to the dissolution of the monopoly of the publicly-owned media organizations in Nigeria, which held a monopoly and were on a steady increase in terms of their numbers as each state was created and the governor open a medium for their country. However, this study focused on the challenges the private broadcast media faced in operations and how they strive to keep afloat. The functionalist theory, pluralist, and Marxist theories created a fundamental basis for the research work. Using the survey method and questionnaire instrument, the researcher gathered responses from 60 respondents at AIT, Yenagoa, who occupied different organization positions. Thus, the researcher analyzed the data and came up with the findings that even to date, funding, access to equipment, power supply, government regulations, and the need to fully attain digitalization were some of the challenges confronting the African Independent Television (AIT), Yenagoa and by implication the private broadcast media. Therefore, the government, its agencies, CBN, and other stakeholders have been advised to help create a soft landing for private media. They have contributed a lot to improving programs' quality, faster access to new, objective, balanced reporting, and the likes.

This is an open access article under the CC-BY-SA license.

\section{Introduction}

Broadcasting is a powerful medium capable of molding the opinion of the audience. Nwabuzor and Gever state that the manner of broadcasting frame issues influence the way the audience perceives them [1]. Jain sums the power of the broadcast media; thus, "this great and modern invention has been instrumental in social awakening, mass education, entertainment, business, and employment [2]. Its reach is wides broadcasting has revolutionized our life. It is the quickest, cheapest, and most popular means of communication. It has helped us conquer space and time. The above definition five an idea of how powerful relevant the broadcast media have been in society. Hence, Ariye asserts that broadcasting is a global phenomenon and an essential aspect of any nation's social and cultural life [3].

However, the broadcast media in Nigeria did not start this way. Before the 1990s, the broadcast scene was purely dominated by the publicly-owned medium. It took till 1992 for the deregulation of 
the broadcast sector in Nigeria to allow for private ownership of the broadcast media. Even during the era of public ownership, the broadcast media was plagued with a plethora of issues. And the inclusion of the private broadcast station did not eliminate these problems. Instead, the private sector became bogged by several challenges as well.

Gever states: The deregulation of the broadcast media in 1992 by the then military administration of General Ibrahim Babangida was, indeed, to widen the scope of broadcasting and subsequently allow private participation [2]. Part of the motivation behind the policy was for Nigerians to reap the full benefits of broadcasting. Decree No. 38 of 1992 set up a regulatory body known as the National Broadcasting Commission (NBC) as a follow-up of the system [4]. NBC states that broadcasting must serve the interest of the general public. It writes: Broadcasting organization shall recognize that they exercise freedom of expression as agents of the society, not for any personal or section rights, privileges and proprietors, relatives, friends, or supporters.

With the submission above, broadcast stations, irrespective of the ownership pattern, are duty bodies to serve the Nigerian public. Adamu, cited in Oketunmbi, observes that deregulation of the industry had thrown up new challenges in a sector that was calm, flat, and dull [5]. The constitution of the Federal Republic of Nigeria (FRN, 1999) also allows private ownership of broadcast stations as it writes in section 39 (2) "without prejudice to the generality of subsection (1) of this section, every person shall be entitled to own, establish and operate any medium for the dissemination of information, ideas, and opinions."

Running a private broadcast station involves a lot of human and material resources. A broadcast station relies heavily on machinery and technology to function. It also depends on technicians and experts with the knowledge to make things work. Broadcasting is capital intensive; thus, broadcast stations, mainly television, require massive funding, which is often hard to get. In developing economies, public stations get subventions annually from the government and are usually better funded than their privately-owned counterparts. For this reason, the former is better positioned to procure several operating facilities for ease of operations. Even at that, subventions hardly meet all needs, given the government's competing demands [6].

The implication of this is that a broadcast organization that is anxious to meet its needs must make internally generated revenue a prime function. Under the circumstance, the Marketing department is automatically made a frontline department in the system because how much it can cause is a crucial factor in the continued viability of the station and its parts. Consequently, a production department has to run as an ally of the revenue yielding department. The latter being similarly conscious that it can only sell good quality content, also recognizes departmental interdependence's expedience. For this to happen, each department's management has to fully realize that when people are assembled to perform a task, the division of the study into several parts should not blur the fundamental principle that all those involved have the same goal.

\section{Theorical Framework}

\subsection{Broadcasting and Technology in Nigeria}

The Africa independent television, a subsidiary of DAAR communications, was borne out of the pan cum - humanist vision of the founder, Chief Aleogho A. Dokpesi, who holds a doctorate in marine transport engineering the University of Gdanski, Poland [7]. The founder's vision is to rapidly integrate the African continent with the rest of the world to encourage development in Africa by attracting investors from all over the world through communications. He desired to bridge the yawning gap in the world's information order, which perpetually places Africa and third world countries at the mercy of the western perspectives' opinions and nuances. DAAR Communications is a Private Independent Communication outfit based in Lagos, Nigeria's former federal capital, and the West Africa sub-region economic nerve center [8].

DAAR communications were incorporated in August 1998. It boasts of successful background in the closely related fields of printing and publishing [9]. DAAR launched its Broadcast Services in 1994 with the promotion of Nigeria's first private radio station, "RayPower" $100.5 \mathrm{FM}$ commenced operation officially in April 1999; before then, DAAR Communications has launched a 24hours global television Services [10]. African Independent Television (AIT) has a philosophy that uses geared towards promoting African values and black people's traditions across the world [11]. 
Iredia states that broadcasting is premised on technology [6]. Because technology keeps changing by the day, a station that is not managed correctly is not likely to benefit from using the latest facilities. In which case, except for a station's management is proactive, obsolete and analog facilities could mar its operatives' efforts. The same fate could more easily befall a broadcast station in the area of regulation. Indeed, the need to apply management principles to broadcasting had become more evident since 2004, when the deadline for the transition to digital broadcasting was conceived by the International Telecommunication Union (ITU) [12]. Again, part of managing a station involves monitoring and ensuring compliance with all relevant injunctions and directions.

In Nigeria, the National Broadcasting Commission (NBC), established in 1992, is empowered to regulate broadcasting [13]. The powers of the Commission are quite enormous to the extent that it can revoke the operating license of a station. The Commission has several provisions in its broadcasting code that must not be breached [14]. To do otherwise is to place the fate of a station in jeopardy. Bearing in mind that it is not enough to survive but to be viable and profitable, care must be taken to evolve a management technique or approach that can ensure increased productivity, efficiency, and effectiveness of a station.

The fear that the private owner might abuse the concept of public interest, that he might use his channel as a political tool against his opponents [15], and that fairness might be sacrificed at the altar of commercially minded proprietors. Ikechukwu Amaechi in Ariye states that the deregulation elicited great enthusiasm from the people and understandably so since the NTA had inextricably become the government's propaganda instrument [3].

He further emphasized that the enthusiasm and absolute craving for private television by the people were predicated on the belief that like the print media, the independent electronic media was going to provide independent news and entertainment, which will inevitably create variety and choice as well as a competition which is expected to rub-off positively on the discerning and sophisticated Nigerian public.

Thus, outlines the ten challenges experienced by private broadcasting in Nigeria and, by extension, AIT, Yenagoa to include [16]; Poor Remuneration; Digital Broadcasting is Still the Least Developed Broadcasting Channel in Nigeria; Broadcasting is Capital Intensive in Nigeria; Most Nigerian Broadcasters are not Properly Groome; No Freedom of Speech; Erratic Power Supply; Poor Infrastructural Development; Poor Quality of Programmes; Non-Payment of Salaries; Poor Welfare.

\subsection{Functionalist theory}

Functionalist theory was created by Herbert Spencer and made notable by Emile Durkheim into the twentieth century. All functionalist theories examine the social universe as a system of interconnected parts to be analysed in terms of their consequences or functions for the larger system [17]. The main focus of the functionalist theory includes that: Culture is made up of interacting, interdependent parts; shared values and expectations, needs, requisites among the members of the society help to hold the society together [18]. These systems have a need for stability and a need to try and keep all the parts working together congruously in a sort of system. There are certain institutions, among them to include the family, the political system, religion, economy, etc. which aid the structure of society [19]. Those institutions, working in order and harmony will not only increase the stability of the social stratification, but will add to it [20]. The functionalist will then point out that these institutions while independent of each other have a shared system of values which guides them and helps hold the society together [21]. In line with the research purpose therefore, the functionalist theory comes from the angle of the relevance of the private broadcast station in the whole, which is the Nigerian society. The private broadcast station and other aspects of society have a shared system of values but to function adequately take more effort.

\subsection{Pluralist and Marxist theory}

Sociologists are interested in the mass media because of the powerful effect in people's lives both politically and socially [22]. Mass media is a form of communication directed to big mass audiences without any personal contact [23]. This can be by radio, television, internet, billboards, and so on. This essay is going to explain and critically evaluate the Marxist and pluralist theories of the mass media. An explanation of the media will also be included. Marxist theorists suggest that the media is dominated by the ruling class who are the media corporations' principal owners, which gives them 
total control and manipulation of media content and audiences in their interest [24]. In the Marxist view, the media is seen as part of an ideal ground in which various class views are battled out [25]. However, pluralists suggest that there is no dominant ruling class [26]. They insist that the role of the media is to promote freedom of speech [27][28]. They see society as a multipart of rival groups and interests, of which none take the top part all of the time [29]. Pluralists believe that the government has a crucial position in regulating media content and ownership [30].

\section{Method}

The researcher adopts the survey research design. This research covers the media practitioners at African Independent Television, (AIT), Yenagoa, Bayelsa State.

Table 1. Distribution of Respondents by Designation at AIT, Yenagoa

\begin{tabular}{lcc}
\hline \multicolumn{1}{c}{ Designation } & Frequency & Percent \\
\hline Reporter & 11 & 20 \\
\hline Head, programs & 3 & 6 \\
\hline Newscaster/ AOP & 9 & 16 \\
\hline Technical/ Production crew & 15 & 27 \\
\hline Editor & 4 & 7 \\
\hline ICT \& Library & 5 & 9 \\
\hline Producers & 8 & 15 \\
\hline Total & 55 & 100 \\
\hline
\end{tabular}

The table 1 shows the designation of the respondents of AIT, Yenagoa that provided responses. Fifteen respondents or $27 \%$ of the sampled population at AIT, Yenagoa are part of the technical or production crew, $20 \%$ or 11 respondents are reporters at AIT, Yenagoa, 9 respondents of $16 \%$ of the sampled population are newscasters or On Air Personalities at AIT, Yenagoa, 8 respondents or 15\% of the sampled population from AIT, Yenagoa are programmed producers. Those in ICT \& Library unit of AIT, Yenagoa accounts for 5 respondents or $9 \%$ of the sampled population, 4 respondents of $7 \%$ are editors and 3 respondents of $6 \%$ of the sampled population occupy the position of Head of program at AIT, Yenagoa.

\section{Results and Discussion}

The dynamics of television in Nigeria is always interesting to follow. As the author stated earlier, television plays a very important role during the COVID-19 pandemic. The author has conducted tracing by contacting several credible sources and carefully selected to maintain the validity of the data. Based on the various data the author has obtained, there are several things that can be described.

Table 2 shows that $66 \%$ of the sampled population, making 36 respondents, indicate that they are aware of the management challenges confronting AIT, Yenagoa. In comparison, 19 respondents of $35 \%$ of the sampled population are partially mindful. No respondents indicated not being aware of the operational challenges facing AIT, Yenagoa.

Table 2. Respondent's awareness on the challenges confronting AIT, Yenagoa in terms of operations

\begin{tabular}{lccc}
\hline & Responses & Frequency & Percent \\
\hline Yes & 36 & 65.5 \\
\hline No & - & - \\
\hline Partially & 19 & 34.6 \\
\hline Can't say & - & - \\
\hline Total & 55 & 100 \\
\hline
\end{tabular}

Table 3 shows how informed about the challenges AIT, Yenagoa in terms of its operational activities. A total of 36 respondents, or $66 \%$, agrees in strong terms that AIT, Yenagoa has challenges; 15 respondents, or $27 \%$ of the sampled population, also concur that AIT, Yenagoa faces 
operative challenges while four respondents, or $7 \%$ of the sampled population agree that AIT, Yenagoa has operational challenges. No respondents share a different view or not knowing that AIT, Yenagoa has operational challenges.

Table 3. Distribution of responses: AIT, Yenagoa has a lot of challenges with regards its operational activities

\begin{tabular}{lcc}
\hline \multicolumn{1}{c}{ Responses } & Frequency & Percent \\
\hline Strongly Agree & 36 & 66 \\
\hline Agree & 15 & 27 \\
\hline Partially Agree & 4 & 7 \\
\hline Disagree & - & - \\
\hline Strongly Disagree & - & - \\
\hline Total & 55 & 100 \\
\hline
\end{tabular}

For table 4, respondents or staff of AIT, Yenagoa identified some of the organization's challenges. Eight respondents, or $15 \%$ of the sampled population, indicate that government and regulatory agencies interference with AIT, Yenagoa operational activities. The operating cost of running AIT, Yenagoa, poses a challenge identified by nine respondents or $16 \%$ of the sampled population. The lack of standard equipment was indicated as an operational challenge by seven respondents, or $13 \%$, while access to power was viewed as a challenge by five respondents or $9 \%$ of the sampled population. Three respondents, or $6 \%$ of the people, believe that the full switch from analog to digital broadcasting faces AIT, Yenagoa. However, 23 respondents or $42 \%$ of the sampled population, accounting for the highest number of respondents, indicated that most of the challenges listed constitute an operational challenge for AIT, Yenagoa.

Table 4. Distribution of responses: Operational Issues confronting AIT, Yenagoa

\begin{tabular}{lcc}
\hline \multicolumn{1}{c}{ Responses } & Frequency & Percent \\
\hline Full switch from analog to digital broadcasting & 3 & 5.5 \\
\hline Technical knowhow & - & - \\
\hline Operational cost & 9 & 16.4 \\
\hline Lack of skilled broadcasters & - & - \\
\hline Lack of standard equipment & 7 & 12.7 \\
\hline Power supply & 5 & 9.1 \\
\hline Government and regulatory agencies interference & 8 & 14.6 \\
\hline All of the above & 23 & 41.8 \\
\hline None of the above & - & - \\
\hline Total & 55 & 100 \\
\hline
\end{tabular}

For table $5,66 \%$ of the sampled population of 36 respondents agree that funding is a significant need for AIT, Yenagoa, like every other private station. Twenty-six percent of the sampled population, representing 14 respondents, agree that budget is an issue for AIT, Yenagoa. In contrast, five respondents, or $9 \%$ of the people, see funding partially confronting AIT, Yenagoa.

Table 5. Distribution of responses: Running a private broadcast station successfully takes a lot of funds

\begin{tabular}{lcc}
\hline \multicolumn{1}{c}{ Responses } & Frequency & Percent \\
\hline Strongly Agree & 36 & 65.5 \\
\hline Agree & 14 & 25.5 \\
\hline Partially Agree & 5 & 9.1 \\
\hline Disagree & - & - \\
\hline Strongly Disagree & - & - \\
\hline Total & 55 & 100 \\
\hline
\end{tabular}


In table 6,16 respondents, or $29 \%$ of the sampled population, which is the highest population, think that AIT, Yenagoa, is not doing enough to evolve with the rest of the world in terms of its operational activities. On the contrary, 15 respondents, making 27\% of AIT, Yenagoa staff, see the station as working hard to move with the trend, 11, respondents or $20 \%$, think AIT, Yenagoa as doing enough to evolve while 13 respondents or $24 \%$ of the sampled population partially agree that AIT, Yenagoa develops.

Table 6. Distribution of responses: broadcast equipment as well as operations keep evolving and AIT, Yenagoa tries hard to evolve

\begin{tabular}{lcc}
\hline \multicolumn{1}{c}{ Responses } & Frequency & Percent \\
\hline Strongly Agree & 15 & 27 \\
\hline Agree & 11 & 20 \\
\hline Partially Agree & 13 & 24 \\
\hline Disagree & 16 & 29 \\
\hline Strongly Disagree & - & - \\
\hline Total & 55 & 100 \\
\hline
\end{tabular}

In table 7, AIT, Yenagoa staff responded as to if the station attracts enough investment or funding. Thirty-one percent or 17 respondents disagree entirely that AIT, Yenagoa attracts enough funds, 21 respondents, or $38 \%$ of the sampled population do not agree that AIT, Yenagoa attracts enough funds. However, on the flip side, eight respondents, or $15 \%$ of the sampled population, think AIT, Yenagoa attracts good enough funds or investment while three respondents, or $6 \%$ of the sampled population a strongly of the opinion that AIT, Yenagoa attracts good investment or funding.

Table 7. Distribution of responses: Private broadcast stations attract enough investments and funding from the private and public sector

\begin{tabular}{lcc}
\hline \multicolumn{1}{c}{ Responses } & Frequency & Percent \\
\hline Strongly Agree & 3 & 5.5 \\
\hline Agree & 8 & 14.6 \\
\hline Partially Agree & 6 & 10.9 \\
\hline Disagree & 21 & 38.2 \\
\hline Strongly Disagree & 17 & 30.9 \\
\hline Total & 55 & 100 \\
\hline
\end{tabular}

For table 8, respondents identified the likely challenges confronting AIT, Yenagoa with securing funds for operation, and 18 respondents, representing $33 \%$ of the sampled population, indicating that the high lending rates posed a challenge for accessing funds AIT, Yenagoa. Nine respondents identified the terms of repayment as what constitutes a challenge when considering funding for the station. Commercial bank regulations or policies create a challenge for AIT, Yenagoa, as seen by five respondents or $9 \%$ of the sampled population. In contrast, two respondents, or $4 \%$, say the lopsided investment requirements, which are not so favorable to the organization, stands in the way of securing many funds. However, 21 respondents, 38\% of the sampled AIT, Yenagoa population, indicate that all the points mentioned above are challenges confronting AIT, Yenagoa.

Table 8. Distribution of responses: challenges with securing funds or investment opportunities for AIT, Yenagoa and private broadcast stations

\begin{tabular}{lcc}
\hline \multicolumn{1}{c}{ Responses } & Frequency & Percent \\
\hline Commercial bank policies and regulations & 5 & 9 \\
\hline High lending rates & 18 & 33 \\
\hline Issues with terms of repayments & 9 & 16 \\
\hline Lopsided investment requirements & 2 & 4 \\
\hline All the above & 21 & 38 \\
\hline None of the above & - & - \\
\hline Total & 55 & 100 \\
\hline
\end{tabular}


Table 9, 32 respondents, representing 58\% of the sampled population from AIT, Yenagoa, indicated that the station has partially achieved the digitalization of its broadcast operations. However, 18 respondents, representing 33\%, stated, 'No,' meaning the station is yet to digitize its broadcast operations fully. Three respondents, or $6 \%$, said Yes, AIT, Yenagoa has attained full digitalization while two respondents, or $4 \%$ of the sampled population, do not have anything to say.

Table 9. Responses on if AIT, Yenagoa has attained full digitalization of broadcast operations

\begin{tabular}{lcc}
\hline \multicolumn{1}{c}{ Responses } & Frequency & Percent \\
\hline Yes & 3 & 5.5 \\
\hline No & 18 & 32.7 \\
\hline Partially & 32 & 58.2 \\
\hline Can't say & 2 & 3.6 \\
\hline Total & 55 & 100 \\
\hline
\end{tabular}

Table 10 addresses what the AIT staff, Yenagoa thinks, is responsible for the non-attainment of full digitalization. Eleven respondents, $20 \%$ of the sampled population, see funding as the major obstacle stopping AIT, Yenagoa, from attaining complete digitalization. In comparison, eight respondents, or $15 \%$ of the sampled population, thinks the importation of broadcast equipment is a hurdle for AIT, Yenagoa digitalization operations. Internal issues and resolution are seen by two respondents or $4 \%$ of the sampled population because the digitalization attempt of AIT, Yenagoa, has not taken effect. Finally, 32 respondents, which is $58 \%$ or above one-half of the sampled population, indicated that all the challenges mentioned had been a stumbling block towards attaining a full digitalization of AIT, Yenagoa.

Table 10. Distribution of responses: challenges with full digitalization of the AIT, Yenagoa

\begin{tabular}{lcc}
\hline \multicolumn{1}{c}{ Responses } & Frequency & Percent \\
\hline Funding & 11 & 20 \\
\hline Importation of broadcast equipment & 8 & 14.6 \\
\hline Issues with government regulatory framework for digitalization & 2 & 3.6 \\
\hline Internal issues and resolution & 2 & 3.6 \\
\hline All of the above & 32 & 58.2 \\
\hline None of the above & - & - \\
\hline Total & 55 & 100 \\
\hline
\end{tabular}

In table 11, AIT, Yenagoa staff, indicated whether or not the private broadcast stations in Nigeria have helped the broadcast scene in Nigeria. A total of 27 respondents, or $49 \%$ of the sampled population, which accounts for almost half of the community, strongly agree that Nigeria's private broadcast station has contributed immensely to the growth of broadcasting in Nigeria. Another 21 respondents of $38 \%$ agree that private broadcasting has helped improve the broadcast sector. In comparison, seven respondents, or $13 \%$ of the population, are in partial agreement on private broadcasting contributions in Nigeria's media. However, no respondent disagreed that private broadcasting has helped improved the broadcast sector in Nigeria.

Table 11. Distribution of responses: Private broadcast stations like AIT, Yenagoa have helped to improve broadcasting in Nigeria

\begin{tabular}{lcc}
\hline \multicolumn{1}{c}{ Responses } & Frequency & Percent \\
\hline Strongly Agree & 27 & 49.1 \\
\hline Agree & 21 & 38.2 \\
\hline Partially Agree & 7 & 12.7 \\
\hline Disagree & - & - \\
\hline Strongly Disagree & - & - \\
\hline Total & 55 & 100 \\
\hline
\end{tabular}


Table 12 shows the contributions or benefits of AIT, Yenagoa, and by implication, the private broadcast station to broadcasting in Yenagoa State. Eleven respondents, representing $20 \%$ of the sampled population, says AIT, Yenagoa has helped ensure faster news delivery. Nine respondents, $16 \%$ of the sampled population, state that better program quality is the added value of AIT, Yenagoa, to the country. Eight respondents, $15 \%$ of the sampled population, say that AIT, Yenagoa, has brought about objective reporting in Yenagoa and Bayelsa State. Six respondents, $11 \%$ of the sampled population, say AIT, Yenagoa has brought about creative and improved program content in broadcasting in Bayelsa State. Finally, 21 respondents, which is 38\% of the sampled population, says all the above benefits have been part of AIT's contributions, Yenagoa, to the broadcast sector.

Table 12. Distribution of responses on the values AIT, Yenagoa have added to broadcasting in Yenagoa State

\begin{tabular}{|c|c|c|}
\hline Responses & Frequency & Percen \\
\hline Faster news delivery & 11 & 20 \\
\hline Better program quality & 9 & 16 \\
\hline Objective reporting & 8 & 15 \\
\hline Feedback and audience participation & - & - \\
\hline Creative and improved program content & 6 & 11 \\
\hline All of the above & 21 & 38.2 \\
\hline None of the above & - & - \\
\hline Total & 55 & 100 \\
\hline
\end{tabular}

\subsection{The challenges confronting AIT, Yenagoa as a private broadcast station in Nigeria}

No doubt, the challenge before the broadcast sector is enormous. Furthermore, the private broadcast sector faces a stiffer challenge considering that they do not have access to government subventions - table 8 outlay the issue of financial challenges confronting the remote broadcast station. The majority of the respondents identified lopsided investment policies, commercial bank and CBN regulation, irregular repayment terms, and high-interest rates as some of the financial woes AIT, Yenagoa has to contend with. Rodney (2004) states that the industry requires hefty capital outlay in state of the art technology to operate efficiently: transmitters, computerized control rooms with teleprompters, comp-graphic switches, studio cameras, recorders, cassettes and tapes, players and mixers, editing suite, OB vans, digital studios, websites, generating plants, etc. The high cost of importing this equipment and lack of regular power supply became problems early in stations' lives. Many stations were unable to secure enough foreign exchange from the Central Bank of Nigeria $(\mathrm{CBN})$, procure equipment, and most challenging, import duties on broadcast equipment.

Table 8, the majority of the respondents identified that AIT, Yenagao, is yet to attain the digitalization of its broadcast operations fully. Armstrong (2018) states that, together, the tremendous benefit can be achieved through digital switchover. These benefits include an increase in efficiency in the use of spectrum and the launch of new services for viewers, which helps secure the future of terrestrial television as a viable economic platform. As countries increasingly adopt digital TV technology, analog TV will become obsolete, making its maintenance difficult and costly. Further challenges are identified in table 10 and have to do with the problems with importing broadcast equipment and government regulatory agencies.

\subsection{How likely is it for private broadcast stations like AIT, Yenagoa to attract investments and funding in Nigeria}

Though it is possible for AIT, Yenagoa to access funding and investment opportunities, the respondents identified that there had been so many pitfalls towards receiving funding from both private and public sources. Therefore, Tables 7 and 8 address the possibilities and challenges with securing funds for AIT, Yenagoa. Under table 7, most of the respondents admitted that securing funds for operations does not come easy from the private or public sector. Therefore, under table 7 , government framework and agencies were selected as barriers to funding. The high lending rate, $\mathrm{CBN}$, and commercial bank regulations also frustrate AIT, Yenagoa's attempt to secure its operations. 
Responses under table 9 show that most of the respondents see AIT, Yenagoa, as not fully attained digitalization of its broadcast operations, which has been a significant challenge to its operations. Though there are high prospects for the full cross over from analog to digital broadcasting, as identified under table 10, government policy framework and the importation of the required equipment have been a significant constraint to achieving this arduous task.

It is evident that private broadcast, which came to be after decree 38 of 1992, was passed under General Ibrahim Babangida's administration and has done better than harm to the Nigerian broadcast scene. Hence, most of the responses under table 11 admitted that the private broadcast station has indeed contributed immensely to the growth of broadcasting in Nigeria. Under table 12, the specific areas itemized include faster new delivery, better quality programs, and content, objective reporting, creative and improved program content are some of the few contributions.

\section{Conclusion}

The study was able to reach the following conclusions that there is a clear fact that the private broadcast media in Nigeria is in dire need of help as it is undergoing several challenges, and deregulation of the broadcast sector gave rise to remote broadcast. The advent of private broadcasting in Nigeria has resulted in the improvement of the broadcast sector in Nigeria. It has resulted in better program content and quality. Also, faster news delivery has become possible with the introduction of the private sector. Also, private broadcast media have faced a significant problem with funding issues. Part of these financial issues has to do with CBN and commercial bank policies, which has made it difficult to access funds. Private broadcast stations can access funds, the repayment terms are either not favorable, or the lending rates are too high. Government policies and frameworks have not helped the private sector to function without any issues. Remote broadcast stations do not enjoy subventions like government-owned stations, and government policy framework has been a limiting factor for private broadcasting stations. There are also issues of molestation and harassment of media practitioners, particularly from the private broadcast stations and by the law enforcement agents overs issues relating to the carrying out of their activities as journalists as well as the problem of erratic power supply has resulted in more cost in terms of operations for private broadcasting stations.

No doubt, deregulation has made an appreciable impact on the country's socio-cultural, economic, and political life. However, it is seen that if the broadcast sector must continue to enjoy the gains of broadcasting, then the private media owners and the government must create an enabling environment for the industry to thrive. There is an urgent need for taxes on the importation of broadcast equip to be cut drastically if not obliterated to aid the importation of broadcast equipment. All stakeholders in the financial sector, including commercial banks, industrial banks, and the likes, need to create relevant and specific packages targeted at the broadcast media to aid their operations and access better funds to keep the broadcast station viable and meet their production standard. Media operators also need to be very conscious about staff salary and remunerations. The welfare of the broadcast media personnel is paramount to ensuring that the staff gives their best to their duties. The media must remain true to their stand on objectivity, fairness, and objective reporting. The media must strive to keep society informed and enlightened about the happenings in the community. NBC has its statutory responsibility to monitor the private broadcast media's activities to ensure they stick to the tenets of broadcasting, informing the public, enlightening, and educating the public while remaining objective. Lastly, government interference in media activities and police harassment of media practitioners has to stop for the media to carry out its functions without fear and rancor.

\section{References}

[1] V. C. Gever and M. Nwabuzor, "Who makes the news? An appraisal of Nigerian broadcast media sensitivity to gender balance," Ibadan J. Gend. Stud., vol. 1, pp. 119-146, 2014.

[2] C. V. Gever, "Comparative Analysis of Public and private Broadcast Media Surveillance of the Boko Haram Insurgency in Nigeria," Int. J. Cris. Manag., vol. 5, pp. 22-30, 2015.

[3] E. C. Ariye, "The Impact of Private Broadcasting in Nigeria," Pakistan J. Soc. Sci., vol. 7, no. 6, pp. 415-423, Jun. 2010, doi: 10.3923/pjssci.2010.415.423. 
[4] Constituteproject.org, Nigeria's Constitution of 1999. Nigeria, 2020.

[5] E. O. O. Oketunmbi, "No TitleGains and pains of liberalization of broadcasting in Nigeria: A critical assessment," Gains pains Lib. Broadcast. Niger. A Crit. Assess., vol. 1, no. 2, pp. 51-62, 2007.

[6] I. Tonnie, "Broadcast Management in Nigeria: The systems approach as an imperative," J. Bus. Manag., vol. 17, no. 12, pp. 26-33, 2015, doi: 10.9790/487X-171232633.

[7] Project Clue, "The Effect of Private Media Houses on Nigeria Economy," 2020.

[8] Project Regards, "Communication: The Key in Effective Public Relation (The Study of DAAR Communication Limited)," 2020.

[9] I. W. Udomisor and A. Sonuga, "Handling Communication Crises in Media Organization the Case of Africa Independent Television," Res. Humanit. Soc. Sci., vol. 3, no. 2, pp. 62-71, 2013.

[10] G. Njoki, "The Political Economy of Deregulation and Commercialization of Radio Broadcasting in Nigeria, 1992-2017," Universitat Autònoma de Barcelona, 2018.

[11] L. Ibraheem Diso, "Information production, transfer, and delivery: Mass information work and television Journalists' dilemma in Nigeria *," Int. Inf. Libr. Rev., vol. 37, no. 4, pp. 285-294, Dec. 2005, doi: 10.1080/10572317.2005.10762686.

[12] The International Telecommunication Union (ITU), "INTERNATIONAL TELECOMMUNICATION UNION - RADIOCOMMUNICATION SECTOR ITU-R FAQ on the DIGITAL DIVIDEND and the DIGITAL SWITCHOVER,” Geneva, 2012.

[13] Project Clue, "the implication of national broadcasting commission rules and regulations on broadcast media," Project Clue, 2020. [Online]. Available: https://www.projectclue.com/broadcasting/projecttopics-materials-for-undergraduate-students/the-implication-of-national-broadcasting-commissionrules-and-regulations-on-broadcast-media.

[14] S. A. Marcello and S. G. Cecilia, "Legislation on community radio broadcasting: comparative study of the legislation of 13 countries," 2003.

[15] O. F. E. CO-OPERATION and A. DEVELOPMENT, Managing Conflict of Interest in the Public Sector. 2005.

[16] C. Azubuike and S. I. G. Ikiriko, "Challenges and Prospects of Private Broadcast Media Ownership in Nigeria: A Study of Stations in Port Harcourt," Mediterr. J. Soc. Sci., vol. 10, no. 5, pp. 90-98, Sep. 2019, doi: 10.2478/mjss-2019-0070.

[17] M. J. Thompson, “A functionalist theory of social domination,” J. Polit. Power, vol. 6, no. 2, pp. 179199, Aug. 2013, doi: 10.1080/2158379X.2013.805922.

[18] S. Clegg, "The state, power, and agency: Missing in action in institutional theory?," J. Manag. Inq., 2010, doi: 10.1177/1056492609347562.

[19] M. Shanks, "Social theory," in Encyclopedia of Archaeology, 2008.

[20] C. Nord, Translating as a purposeful activity: Functionalist approaches explained. 2018.

[21] D. C. Lane, "Social theory and system dynamics practice," Eur. J. Oper. Res., 1999, doi: 10.1016/S0377-2217(98)00192-1.

[22] J. Scott, Fifty Key Sociologists: The Contemporary Theorists. 2007.

[23] R. D. Wimmer and J. R. Dominick, Mass media research: an introduction. 2011.

[24] P. Goldstein, Post-marxist theory: An introduction. 2005.

[25] D. Karen, "Marxism, Cultural Studies and Sport," Contemp. Sociol. A J. Rev., 2010, doi: 10.1177/0094306109356659h.

[26] M. Arboleda, "Revitalizing science and technology studies: A Marxian critique of more-than-human geographies," Environ. Plan. D Soc. Sp., 2017, doi: 10.1177/0263775816664099.

[27] B. Van Besien, "Does Media Policy Promote Media Freedom and Independence? - The Case of Belgium," SSRN Electron. J., 2012, doi: 10.2139/ssrn.2034242. 
[28] S. Stier, "Democracy, autocracy and the news: The impact of regime type on media freedom," Democratization, 2015, doi: 10.1080/13510347.2014.964643.

[29] A. Quinn, "Moral Virtues for Journalists," J. Mass Media Ethics, 2007, doi: $10.1080 / 08900520701315764$.

[30] B. Klimkiewicz, "State, media and pluralism: Tracing roots and consequences of media policy change in Poland," Publizistik, vol. 62, no. 2, pp. 197-213, May 2017, doi: 10.1007/s11616-017-0337-5. 